\title{
The revelation and Practice of the multi-level, multi-direction education model of the American Community Colleges
}

\author{
Yuewei Ding \\ Shanghai Medical Instrumentation College \\ University of Shanghai for Science and Technology \\ Shanghai, China \\ e-mail: dingyw@smic.edu.cn
}

\section{Li Wang}

Shanghai Medical Instrumentation College

University of Shanghai for Science and Technology Shanghai, China

e-mail: wangl@smic.edu.cn

\begin{abstract}
This paper describes the positioning and advantages of the American community colleges, analyzes the characteristics of the community colleges and revelation to Higher Vocational Education in China, compares the higher education system in China and the United States, summarizes the practice experience for the demonstration construction of Shanghai Medical Instrumentation College(SMIC), learning from the multi-level, multi-direction education model of community colleges, provides valuable theoretical basis and practical experience for the development of vocational education in China.
\end{abstract}

Keywords-Community College; vocational education; college-enterprises cooperation

\section{INTRODUCTION}

In order to learn from the experience of the education of American community colleges, the writer had the honor to participate in the 2010 "Vocational Education Leadership Overseas Training programs” organized by China Education International Exchange Association. The leaders visited the Highline Community College, Green River Community College, Miami Dade College Medical Campus and other institutions in the United States such as Higher Education Accreditation Committee, vocational and adult education office for learning, studying and training in order to have a relatively comprehensive in-depth understanding and experience of the unique educational model and management, operational mechanism of the education system in the United States, especially the American community colleges. Combined with the actual situation of SMIC, the writer fully draws on the experience of the multi-level, multi-direction education model of the American community College and discusses about the practice and the results of the in-depth study.

\section{THE MAIN FEATURES OF THE AMERICAN COMMUNITY COLLEGE}

In the early establishment period, the community colleges in the U.S. provide mainly the first two years

\author{
Yihong Fu \\ Shanghai Medical Instrumentation College \\ University of Shanghai for Science and Technology \\ Shanghai, China \\ e-mail: fuyh@smic.edu.cn.com \\ Hong Chen \\ Shanghai Medical Instrumentation College \\ University of Shanghai for Science and Technology \\ Shanghai, China \\ e-mail: chenh@smic.edu.cn
}

undergraduate courses for students with lower fees. They provide students with open post-secondary education programs for all ages, all income classes. Thanks to the complete credits system of the community college, both fulltime and part-time students have the same learning opportunities and conditions, according to the latest statistics from the American Association of Community Colleges, $41 \%$ of the students are full-time students and $59 \%$ of them are part-time students. Community Colleges adopt the open enrollment policy to encourage and support all citizens from all over the world with different cultural backgrounds to learn. The students have to pass through the admission test and make sure what level courses they can learn.

\section{A. Multi-direction Education Model}

In the higher education system in the United States, the Community College's unique characteristic embodied in its strong dependence, government funded background and strong regional characteristics. The government and the third parties participate and support the development of the community Colleges. The community college system is established in accordance with the principles of democracy; its administration structure can be divided into several parts of State Government and Community Colleges. The State government appointed Board of the State community college system, then there are executive officers hired by the state board and his office of the State community college system, they are responsible for the related policies and developing plans, financial budget, tuition standard control of the community colleges and professional settings. There are also board in the college appointed by the government or elected and the board members are celebrities who are enthusiastic about community development and obliged to do the community and college work for free, they are responsible for the selection of college principal, supervise the principals performing their duties. On the other hand, based on the characteristics of the federal government in U.S., different state community colleges have different administration models and specific architectures. For example, the City University of New York has the biggest the advantage that 
the community college can be used as a gateway into the City University of New York; Miami Dade Community College, (MDC): adds a district level "school district" between states and colleges, the government appointed or elected democratically the board ,then the board appointed Vice-Chancellor of a multi-campus community college; The Highline Community College: cover some communities, and they focus on a relatively small, specific area where it is convenient to arrange vocational training courses as well as a community service.

\section{B. Multi-level Choices}

There are much in common in the tasks and advantages in U.S. community colleges .But each community college has its distinctive characteristics according to their state and the region's cultural and geographical environment, and social needs. The community colleges tend to be in accordance with the wishes of the students and the actual situation of the society, they provide the flexible and diversified approaches for students to choose: (1) the twoyear transfer education. For the purpose of pursuing the associate degree education, the community colleges and state universities signed an agreement that the two sides have mutual recognition of credits, which provides institutional protection for the community college's associate degree students continue to enter university learning; (2) Vocational and Technical Education. They provide credit courses and non-credit courses in different time lengths. The universities recognize credits for Transfer Education and the community colleges also offers vocational skills training and relevant national, state or industry professional certificate examinations when the students entering society; (3) community service, the community colleges provide mainly vocational skills training courses, including the graduates who have been working in order to improve themselves and the need to transfer jobs such as MDC, it provides senior technical certificate, career certificates, vocational education or health projects.

\section{THE COMPARISON AND INSPIRATION OF EDUCATION SYSTEMS IN CHINA AND THE UNITED STATES}

Government gives priority to the development of education, in the background of increasing investment in education how to expand and improve vocational education in the public service, how do the government spend money and spend money good is a problem. Good public policy should strive to make up for those shortcomings, pursue a balanced and coordinated development of all types of education, at the same time avoid creating new problems and the formation of education wasted. Figures 1 and 2, illustrates the United States as well as China's education system respectively, two of the country's basic education system are similar, but there are still some differences in the details.

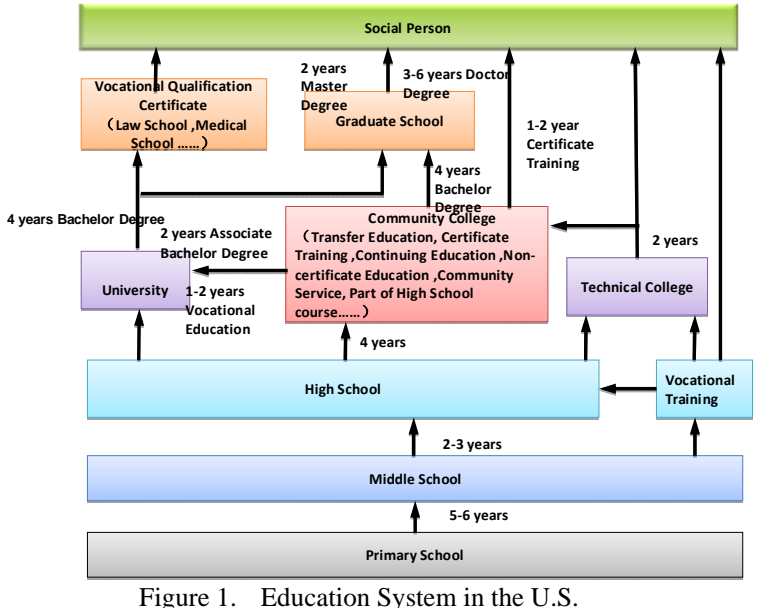

The education system of USA is essentially a "one-line" dominated education system which is an academic path of development composed of primary schools, secondary schools, high schools, universities, graduate. Community colleges are similar to our traditional three-year college in the aspect of learning, in addition to taking a low tuition, welcoming all citizens policy which embodies everyone the equal right of getting higher education, the community college also take the functions of vocational education into account and train of a group of technical personnel and senior technical personnel. At the same time, the community colleges also provide a wide range of functions of continuing education, training, certificate training and community culture.

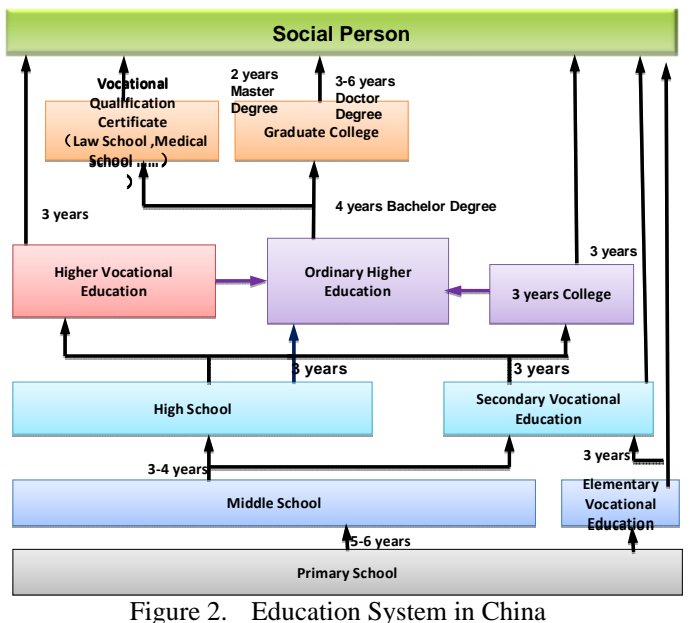

In China, secondary vocational education and higher vocational education occupies a large proportion of the higher education.Thus we can learn from the experience of foreign vocational education, draw on the strengths of community colleges in the United States, in order to develop vocational education and secondary vocational education vigorously as well as taking the development of colleges and universities in the traditional sense into account, opening up a overpass of vocational education and degree education, in order to adapt to the developing needs of different groups. 


\section{A. Further Clarify the Educational Goals of Vocational} Education at All Levels to Build a Multi-level Vocational Education System

Currently the vocational education in China can be divided into two levels of secondary and higher vocational education and it has not formed a reasonable system of vocational education yet. Viewing the operation mechanism of the American Community College Transfer Education, the function of community colleges in the United States almost cover vocational education, continuing education, TVU, Elearning, training, community cultural centers, etc. in china. Through the learning in community colleges in the U.S., the graduates could choose to study in the university getting vocational training, or go to work directly. According to China's national conditions, we may consider vocational education together with higher vocational education as an organ and explore the higher vocational education model of " three-year college, university and postgraduate" to integrate the vocational education resources and enhance the competitiveness and attractiveness of vocational education.

\section{B. Build the College-enterprises Cooperation Platform and Multi-direction Cooperation Mode in Running College}

We can learn the operating mechanism of collegeenterprises cooperation from Community Colleges. Making the strategic plan or five-year plan team composed of the college teachers, administrators, enterprises, and students, we could make a strategic plan through the internal status research and analysis of the external environment; the college-enterprises cooperation would be done in the decentralized way, thus the college leaders, department heads, faculty and staff can be initiated by the work of the college-enterprises cooperation, at the same time we could sign the different contracts according to the size and importance of the cooperation in order to increase the its mobility; we could encourage students to participate in community service with regards to their specialty; we could set training department in the enterprises which have close cooperation with the colleges in order to make the cultivation plan more effectively and improve the quality of the practical teaching; as for the training base invested by the colleges; the teachers or the part-time teachers from the business could cultivate the students and so on.

\section{REFERENCE AND PRACTICE OF THE AMERICAN COMMUNITY COLLEGE}

Shanghai Medical Instrumentation College was founded in 1960, and became the national demonstration backbone vocational college in November 2010, because it always takes the combination of Medical and Engineering as its characteristics.

\section{A. Multi-direction Cooperation of College-enterprise- hospital-supervision and research}

SMIC gives full play in the development of medical devices vocational education, learning from the collegerunning experience of American Community colleges in education combined with its own characteristics, SMIC establishes the education group council of the collegeenterprise-hospital-supervision and research five-party cooperation, builds an effective college-enterprises cooperation platform, builds "factory in college" and " college in factory" implementation principals factory manager in hand, pushes the faculty construction of "combing the presidents of the universities with the presidents of the factories, masters with the famous teachers, teachers with the technicians ", with the main aim of building together, cultivate together and win-win together to improve the part-time teachers team, explore vocational qualification training programs, expand social services. These have received the good comment from the students, teachers, employers and the society.

\section{B. Explore the Construction of Modern Vocational Education System}

SMIC explores smooth overpass of vocational college and the higher vocational college actively, through learning from the experience of the American community colleges, improves the curriculum setting and mutual recognition of credits for vocational students who take the course of vocational college combined with the higher vocational college. With the advantages of University of Shanghai for Science and Technology system, we could explore the construction of "three year college, university and post graduate" overpass, seeks to strengthen the vocational skills training objectives based on the target of voluntary wish of the students to establish a direct overpass through vocational college to universities.

Of course, we have encountered many difficulties in the reality, such as the level of concern and commitment from the government. Learning from the characteristics and experience of community colleges in the United States, comparing our higher vocational education with the U.S., drawing on the experience and practice actively, we should provide a theoretical and practical basis for the development of China's vocational education.

\section{ACKNOWLEDGMENT}

Our further research of the revelation and practice of the multi-level, multi-direction education model of the American community colleges are supported by Shanghai association of higher education in Research projects ZCGJ59-12.

\section{REFERENCES}

[1] XU Kui-hong, ZHANG Rong-juan. Study Oil the Administration System of Community College in the USA, V0CAT10NAL AND TECHNICAL EDUCATION. 2012, Vol33(16):79-82.

[2] Wu Zhongwen. Times' Call for Vocational Education Ver.3.0, China Youth. http://zqb.cyol.com/, 2013 -1-4.

[3] Zhanran Mao. American community colleges. Wuhan : Wuhan University Press, 2004.

[4] Yixoan Li. American community colleges. Distance Education in China. 2008, http://www.chinagaozhi.org/models/gz/.

[5] Jianmin Chen. The Enlightenment of American community colleges to higher vocational education in China. Beijing Education ,2009, 12. 